\title{
A HÁROMFAKTOROS EVÉSI KÉRDŐíV ALKALMAZÁSI LEHETÓSÉGEI A MARKETINGKUTATÁSBAN - NEM ÉS GENERÁCIÓK KÖZÖTTI ELTÉRÉSEK
}

\author{
- भी० \\ ADAPTATION POSSIBILITIES OF THE THREE FACTOR EATING QUESTIONNAIRE IN \\ THE FIELD OF MARKETING RESEARCH - \\ DIFFERENCES BASED ON GENDER AND GENERATION
}

\author{
10 \\ KELLER, Veronika \\ DERNÓCZY-POLYÁK, Adrienn \\ ERCSEY, Ida \\ is
}

Széchenyi István Egyetem, Kautz Gyula Gazdálkodástudományi Kar, Marketing és Menedzsment Tanszék (Széchenyi István University, Kautz Gyula Faculty of Economics, Department of Marketing and Management) H-9026 Györ, Egyetem tér 1. e-mail: kellerv@sze.hu

Overweight and obesity is an endemic that appears in the developed countries of the world. Overweight and obesity means a serious expenditure for the consumers, for the employers and for the national states both in the prevention and in the treatment phases. In the national and international literature more authors deal with the research of the dimensions of healthy lifestyle either in a complex way or focusing on a special area (e. g. smoking, alcohol consumption, physical activity or eating behavior). There are more tests investigating food consumption, but the most widely used one is the Three Factor Eating Questionnaire (TFEQ). The revised TFEQ (TFEQ 21 and TFEQ 18) scales were validated in Hungary on the population with normal weight and overweight obese individuals and three types of eating behavior were identified, namely (1) emotional eating (EE), (2) cognitive control eating (CR) and (3) uncontrolled eating (UE). The aim of this study is on the one hand to introduce the Hungarian adaptation possibilities of the revised scale (TFEQ 16) measuring eating habits and on the second hand to explore the connections with demographics. In an empirical research 919 adult people were interviewed: $45.2 \%$ males and $54.8 \%$ females. Based on age the authors defined three generations, the "Baby boomers", the $X$ and the $\mathrm{Y}$ generations. Their ratio in the sample is the following: $14.7,42.5$ and $42.8 \%$. Relying on the results of the empirical research it can be said that the adaptation of TFEQ 16 is possible in Hungary. The former explored factor structure is valid among Hungarian population that is adults can be characterized by emotional, uncontrolled and cognitive control eating. The EE and CR are typical eating styles among women and CR is typical for people belonging to Y generation. In the future the authors plan to extend the research to segment the population based on their eating styles in order to develop an effective marketing program for them.

KuLCSSZAVAK: étkezési stílusok, háromfaktoros evési kérdőív, TFEQ 16, generációk

JELKóD: I12, M30, M39
KEYwORDS: eating styles, Three Factor Eating Questionnaire (TFEQ), TFEQ16, generation 


\section{BEVEZETÉS - INTRODUCTION}

A modern piacgazdaság feltételei mellett a fejlett országok lakosságának táplálkozására jellemző a túlfogyasztás, az életvitelükre pedig a mozgásszegény életmód, ami az egyének genetikai adottságainak együttes hatására túlsúlyt, elhízást eredményez (TOLNAY és SZABÓ, 2004). Az OECD (Gazdasági Együttmüködési és Fejlesztési Szervezet) 2014-es közleménye szerint 2012-ben a 15 év feletti lakosságot vizsgálva a szervezethez tartozó 34 országban élő férfiak 17,7\%-a, a nők 18,7\%-a elhízott $\left(\mathrm{BMI}^{1} \geq 30\right)$. Első helyen az Egyesült Államok áll, ahol a lakosság több mint harmadát érinti a probléma. Ezt követi Új-Zéland, Ausztrália és Mexikó. Magyarországon a 15 év feletti lakosság 29\%-a számít elhízottnak (a férfiak 26,3\%-a és a nők 30,4\%-a), ami több mint másfélszerese az OECD tagállamok átlagának. Ezzel az adattal az unión belül is az „élmezőnybe” tartozunk. A KSH 2014-es egészségfelmérése alapján a teljes magyar lakosság több mint fele (54\%) a túlsúlyosak-elhízottak (25 < BMI < 30) közé tartozik. A férfiaknál magasabb ez az arány (61\%), mint a nőknél (48\%), bár a felmérés tapasztalata, hogy a nők alulbecsülik a testsúlyukat és felülértékelik a testmagasságukat, mivel a testtömeg-index megállapítása önbevalláson alapult. Az időbeli összehasonlítás alapján megállapítható, hogy a túlsúlyosak és elhízottak együttes arányát tekintve a középkorú és az idősebb férfiak körében egyértelmú növekedés, a középkorú nőknél inkább visszaesés, míg az idősebb nőknél stagnálás figyelhető meg. A fiatal férfiaknál enyhe visszaesés, a fiatal nóknél pedig kismértékú emelkedés volt jellemző a 21. század folyamán (EURÓPAI LAKOSSÁGI EGÉSZSÉGFELMÉRÉS, 2014). A túlsúly és az elhízás következményeként megjelenő betegségek jelentős anyagi terhet jelentenek egyéni, foglalkoztatói és állami szinten is, mind a megelőzés, mind pedig a kezelés szakaszában. Hazánkban 2216 milliárd Ft (GDP 7,9\%-a) mértékben alakultak az egészségügyi kiadások 2012-ben, amely pénzben kifejezve csaknem $223400 \mathrm{Ft} /$ fó/év volt (KSH 2015).

A nemzetközi és a hazai szakirodalomban az elhízás és az evési magatartás kapcsolatá- nak vizsgálata elsôsorban a pszichológiai és a szociológiai tanulmányokban jelent meg. Viszonylag kevés tudományos munkában olvashatunk a testtömeg menedzselés és az étkezési stílus marketing szempontú elemzéséről, pedig a társadalmi jólét elérése a vállalatok számára is fontos tényező. Jelen tanulmány egy komplex kutatás része, és a kutatás jelenlegi fázisában az evési magatartás fő dimenzióit tárja fel a felnőtt korú népesség körében és bemutatja a nemek, illetve generációk közötti eltéréseket.

\section{Az EVÉSI MAGATARTÁs SZAK- IRODALMI ÖSSZEFOGLALÁSA - LiTERATURE REVIEW CONNECTED TO EATING BEHAVIOR}

A pszichológusok az elhízottak és a normál testsúlyú egyének vizsgálatára több mérési eljárást is kidolgoztak: látens elhízás kérdőív (PUDEL et al., 1975), evési attitűdök tesztje (GARNER és GARNFINKEL, 1979), korlátozás skála (HERMAN és POLIVY, 1980). Jelen kutatásban az élelmiszer-fogyasztói magatartás tesztjei közül a háromfaktoros evési kérdőív (Three Factor Eating Questionnaire - TFEQ) (STUNKARD és MESSICK, 1985, KARLSSON et al., 2000, THOLIN et al., 2005) kerül kiemelésre, mivel ezt a korábbi tesztek alapján fejlesztették ki és validálták a nemzetközi és a hazai szakirodalomban. Választásunkat támasztja alá az a tény is, hogy ennek az eredeti 51 tételes változata (TFEQ 51) és a rövidített 21, valamint 18 tételes (TFEQ 21, TFEQ 18) alkalmazása a legelterjedtebb a pszichológia, és a szociológia tudományterületén belül.

Az eredeti 51 tételes skálát STUNKARD és MESSICK (1985) fejlesztette ki és az egyes állításokat dichotóm (igen-nem) skálán mérték. Három evési stílust azonosítottak: a kérdőív 21 tétele a kognitív korlátozásra vonatkozik, 16 tétel a viselkedésbeli és az élethelyzetek következtében kialakult érzelmi állapotban történő evésre, 14 állítás pedig az éhségre való általános fogékonyságra. A szerzők a három evési magatartás esetében három különböző kategóriát - alacsony, magas, klinikai eset - különítettek el az egyes stílusokra adott „igen” válaszok 
összeadásával. A kognitív korlátozás esetében 0-10 tartozik az alacsony kategóriába, 11-13 a magas, míg a 14-21 pontig a klinikai eset csoportjába. Az érzelmi evés kapcsán o-8 között az alacsony, 9-11 között a magas, míg 12-16 pont a klinikai eset kategóriáját jelöli. A kontrollálatlan evésnél a következő osztályozás alakult ki: 0-7 alacsony, 8-10 magas, 11-14 klinikai eset. A következőkben kiemeljük azokat a legújabb kutatási eredményeket, amelyek az eredeti 51 tételes skálát és annak rövidített 21, illetve 18 tételes változatát használták fel a mélyebb öszszefüggések feltárása érdekében.

HARDEN és szerzőtársai (2009) 60 fős férfiakból álló mintán keresztmetszeti kutatás keretében vizsgálták a BMI és az evési stílusok közötti összefüggést. Az evési stílusok azonosítására az eredeti 51 tételes változatot használták és az összesített pontok alapján különítették el az alacsony, magas és klinikai eset kategóriákat. Két szempontos varianciaelemzés segítségével állapították meg a testtömeg indexszel való kapcsolatot. Az érzelmi evés van a legnagyobb hatással a BMI-re, és az éhségre való fogékonyság magasabb szintje jellemző az elhízott egyénekre szemben az egészséges, normál testsúlyúakkal. Életkor alapján megállapítható, hogy fiatalabb férfiak inkább fogékonyak az éhségre, mint az idősebbek.

LESDÉMA és szerzőtársai (2012) 1000 fős 20-39 év közötti fiatal francia felnőttek evési magatartásának pszichológiai aspektusait vizsgálták a TFEQ 51 segítségével. Az egyes alskálák átlagértékeit hasonlították össze nem, BMI és egyéb társadalmi-demográfiai ismérvek alapján. A francia fiatalok alacsony értékekkel jellemezhetók a visszafogott evés, illetve az éhségre való fogékonyság esetében. E kettő evési stílus esetében a nők magasabb értékekkel karakterizálhatók, mint a férfiak. Nemtől függetlenül az érzelmi evés korrelál leginkább a BMI-vel, vagyis e stílus járul hozzá a túlsúly kialakulásához, végső soron pedig az elhízáshoz. A szerzők a kognitív kontroll étkezési stílus esetében elkülönítették a rugalmas és a szigorú visszafogott kategóriát, az érzelmi evésnél a viselkedésében fogékony, érzelmileg fogékony és bizonyos helyzetekben fogékony eseteket, míg az éhségre fogékonynál a belülről és a kívülről történő fogékonyságot.

LÖFFLER és szerzőtársai (2015) kifejlesz- tették a TFEQ német változatát a középkorú, illetve idősebb (40-79 éves) lakosság körében. 3144 főt sikerült bevonni a kutatásba, akik válaszoltak a TFEQ 51 kérdéseire és jelölték az egyes evési problémákat - édesség iránti vágy, stresszhelyzetben történő evés, alkoholfogyasztás, hirtelen farkaséhség, társaságban történő evés, állandó kalóriaszámlálás, unalom hatására való evés és a túlevéstől való félelem. A nók mindhárom evési stílus esetében magasabb értékeket értek el, mint a férfiak. Az idősekre inkább jellemző a kognitív visszafogott evés, mint a fiatalokra. A fiatalabbak azok, akik érzelmek hatására esznek, illetve fogékonyak az éhségre. A férfiak 45,1\%-a, a nők 69,9\%a számol be valamilyen speciális étkezéshez köthető problémáról. A legmagasabb említési arányt $(38,6 \%)$ az édesség iránti vágy kapta. A fiatalabbakra jellemző a stresszhelyzetben történő evés.

Hazánkban a CZEGLÉDI és URBÁN (2010) egyetemi hallgatók mintáján (262 fó) végezte el a háromfaktoros evési kérdőív rövidített, 21 tételes változatának magyar nyelvre történő adaptációját és pszichometriai elemzését. A kérdőív 20 tétele 4 és 1 tétele 8 fokozatú skálán értékelendő. A keresztmetszeti, kérdőíves kutatás alátámasztotta az eredeti faktorstruktúrát, konfirmatív faktorelemzéssel 3 faktort azonosítottak: 1. Kontrollálatlan evés (9 tétel), 2. Kognitív korlátozás (6 tétel), és 3. Érzelmi evés (6 tétel). A pszichometriai elemzés azonban közepes mértékű vagy gyenge illeszkedést mutatott, ezért indokoltnak látszik további vizsgálatok végrehajtása. A szerző elvégezte a faktorok időbeli stabilitásának ellenőrzését, melynek eredményeként a kontrollálatlan evés és a kognitív korlátozás faktor időbeli stabilitása alátámasztást nyert.

CZEGLÉDI és szerzőtársai (2011) érdeklődése kiterjedt az evési magatartás és a tápláltsági állapot, az étel preferencia, a fizikai aktivitás, valamint a testképpel való elégedetlenség kapcsolatának vizsgálatára. A kvantitatív kutatást főiskolai hallgatónők (295 fó) megkérdezésével végezték el 2008 tavaszán. A várakozásoknak megfelelően az egyes ételek preferenciái és a különböző evési magatartások kapcsolatot mutatnak. A kognitív korlátozás az energiában gazdag ételek kerülésével, a kontrollálatlan evés és az érzelmi evés pedig az 
energia dús ételek preferenciájával jár együtt. A korábbi kutatási eredményeket kiegészítve, szerzők azt kapták, hogy a testtömeg index növekedése az evés tudatos korlátozására való törekvés fokozódásával jár együtt. A kognitív korlátozás nem az önsanyargató diétát jelenti, hanem az egészségtudatos evést. Az evési viselkedés kapcsolatot mutat az egészségmagatartás egy másik aspektusával, a fizikai aktivitással. A rendszeres testedzést végző diákok szignifikánsan magasabb pontszámot értek el a kognitív korlátozás skálán, mint a passzív válaszadók. A testtömeg index növekedésével párhuzamosan a nók egyre távolabb kerülnek a nyugati társadalom által meghatározott női testideáltól. Ez pedig együtt járhat a testmérettel való elégedetlenséggel, ami szerepet játszhat az élelmiszerbevitel korlátozásában. A megkérdezés eredményei alátámasztották ezt a feltételezést, tehát a testméret negatív értékelése közvetítő szerepet tölt be a tápláltsági állapot objektív mutatója (BMI) és a táplálékbevitel kognitív kontrollálása között.

A legújabb kutatások a háromfaktoros evési kérdőív 18 tételes rövidített változatát használták a különféle összefüggések megállapítására. A kérdőív 17 tétele négyfokozatú skálán „teljes mértében igaz”, „egyáltalán nem igaz” végpontokkal, egy pedig nyolcfokozatú skálán mért. A nemzetközi vizsgálatok elsősorban longitudinális, követő kutatást alkalmaztak, hogy megállapítsák melyik evési magatartásmód áll összefüggésben az elhízással és a túlsúly kialakulásával.

KERÄNEN és szerzőtársai (2011) 18 hónapon át tartó kutatás keretében 49 túlsúlyos és elhízott energiabevitelét követték nyomon és elemezték az evési magatartásukat diéta előtt és után. A kutatásban résztvevők vagy rövid távú vagy intenzív tanácsadást kaptak. Az TFEQ 18 változatát használták, a kalóriabevitelt pedig a diéta o. napjától, illetve 18 hónap elteltével öt napon keresztül naplóíró panelok segítségével mérték. Akik rövid távú tanácsadásban részesültek, azoknak magasabb volt a proteinbevitelük. A kognitív korlátozás stílus alacsonyabb energiafogyasztást mutatott, különösen a zsírok szempontjából, viszont magasabb szénhidrátfogyasztást a szacharóz és rostok tekintetében a másfél éves időtáv végén, és ez a csoport tudott a legnagyobb súlyfeleslegtől megszabadulni. A tudatosan visszafogott evés segíthet a kalória bevitel korlátozásában és a sikeres fogyókúra elősegítésében.

KEARNEY és szerzőtársai (2012) feltételezték, hogy az étrendre vonatkozó tanácsadás kevésbé hatékony módszer a súlycsökkentés elérésben, a viselkedés megváltoztatására irányuló programok viszont eredményesebbek az egészségesebb étkezési szokások elsajátításában. A figyelmességen alapuló stresszcsökkentő programok pozitív hatással vannak az evési magatartásra, és a táplálékbevitelre. 48 idős személyt kérdeztek meg a program megkezdése előtt, majd utána, és 4 hónappal a program befejezését követően. A kutatás nem mutatott ki egyértelmú kapcsolatot a program és az étkezési magatartás kedvező megváltozása, illetve a táplálkozási szokások átalakulása között.

NURKKALA és szerzőtársai (2015) az evési magatartás változásait és befolyásoló tényezőit vizsgálták a sikeres diétázók (akik testtömegük 5\%-nál nagyobb súlyveszteséget értek el) körében. 59 túlsúlyos és 17 fős kontrollcsoport adatait követték nyomon 3 éven át. Az evési magatartást a TFEQ 18 kérdőív segítségével vizsgálták, a súlyveszteség motivációit és a különböző problémák tolerálását külön kérdőív segítségével határozták meg. A résztvevők testmagasságát, súlyát mérés alapján állapították meg. A kísérleti csoport nagyobb súlyveszteséget ért el, mint a kontrollcsoport. A kísérleti csoporton belül kétszeresére nőtt a kognitív korlátozás evési stílus, ami pozitívan korrelál a súlyveszteséggel, az elkötelezettséggel és a problémák tolerálásával. A kognitív korlátozás magatartásforma a sikeres és sikertelen diétázók körében is nőtt, de egyedül a sikeres fogyókúrázók voltak képesek csökkenteni a kontrollálatlan evést hosszú távon. Minden életmódváltó program során fontos, hogy az elhízottak folyamatos segítséget kapjanak, megerősítsék őket a céljaik elérésében, segítsenek nekik a problémák tolerálásában. Az intenzív tanácsadás hozzájárul a visszafogott evési stílus elsajátításában, ami a fogyás elsődleges kulcsa.

A hazai szakirodalomban is megjelenik az egészséges életmód aspektusainak vizsgálata, különösen a fiatalok körében (HUSZKA és ERCSEY, 2014), ugyanakkor cikkünkben azokat a kutatásokat ismertetjük, melyek a TFEQ 
kérdőív tesztelésére, az evési magatartás elemzésére irányultak. SOÓS és szerzőtársai (2014) a magyar lakosság egészségmagatartását vizsgálták az evési attitűd és a testi attitüd vonatkozásában. Vizsgálati módszerként a kérdőíves megkérdezést alkalmazták, amelyet 1000 fős országos reprezentatív mintán végeztek el a felnőtt korú népesség körében. A 18 tételes háromfaktoros evési kérdőív, és a „testi attitüdök tesztje” alapján elvégezték a faktorstruktúra meghatározását, majd klaszteranalízist hajtottak végre, amelynek során öt klasztert különítettek el. Az öt klasztert a Kontrollálatlan érzelmi evők, a Feszült elégedetlenek, az Érdektelenek, a Túlsúlyos impulzusevők és a Tudatosan táplálkozók csoportja alkotja. Ez a szegmentáció iránymutató lehet az egészségvédő hatású élelmiszerek gyártói, valamit az egészségmarketing szakemberei számára célcsoportjuk meghatározásához és a fogyasztók megszólítására. Például a Túlsúlyos impulzusevők csoportjában (13\%) egyszerre van jelen a testtömeg csökkentése iránti igény, továbbá az érzelmi és kontrollálatlan evés. Ugyanakkor közel 20\%-nak tekinthető az egészségvédő élelmiszerek elsődleges célcsoportja, a Tudatosan táplálkozók köre. A klaszter tagjaira nem jellemző az érzelmi evés, és anyagi helyzetük alapján megengedhetik maguknak akár a prémium kategóriás termékeket is.

SZABÓ és szerzőtársai (2014) kutatásai során 3 faktort azonosítottak: 1. érzelmi evés (6 tétel), 2. kontrollálatlan evési skála (3 tétel), 3. kognitív korlátozás (3 tétel). A CZEGLÉDI (2010) által validált skála 21 tételéből kizártak 9 tételt, mivel alacsony faktorsúllyal rendelkeztek. Az egyetemi hallgatók evési viselkedésére jellemző (CZEGLÉDI és URBÁN, 2010) faktorok 1. faktora megegyezik a teljes népességre kapott érzelmi evés faktor tételeivel. A 2. faktor esetében 6 tételt eltávolítottak, mivel ezek nem járultak hozzá a kontrollálatlan evés magyarázatához. A 3. faktor pedig 3 tétellel kevesebb állítást tartalmaz a kognitív korlátozásra vonatkozóan, mint a CZEGLÉDI és URBÁN (2010) által alkalmazott skála. Megállapították, hogy a teljes felnőtt populáció evési viselkedésében nagyobb szerepe van az érzelmi evésnek, mint a kognitív korlátozásnak, amit alátámaszt a faktorok magyarázó ereje. Az így kialakított skálák belső konzisztenciájának ellenőrzésére Cronbach alpha értékeket számítottak, amely mindhárom evési stílus esetében o,8 érték felett volt, azaz megbízhatónak tekinthető a mintán folytatott további kutatás lefolytatására.

A bemutatott szakirodalom alapján megállapítható, hogy az érzelmi evés, és az éhségre való fogékonyság (kontrollálatlan evés) hozzájárulnak a túlsúly kialakulásához, elhízáshoz. Nem és életkor viszonylatában az alábbi megállapítások tehetők:

- A nőkre jellemző a kognitív korlátozás evési stílus, illetve az éhségre való fogékonyság. Ugyanakkor a nők esetében mindhárom evési stílus markánsabban jelenik meg, mint a férfiaknál.

- A fiatalabb korosztályra, nevezeten az Y generáció tagjaira jellemző az érzelmi evés, illetve az éhségre való fogékonyság. $\mathrm{Az}$ idősebbekre (X generációra és Baby boom nemzedék tagjaira) jellemző a kognitív korlátozás evési stílus.

\section{Az EMPIRIKUS KUTATÁs MódSzertana - THE METHOD OF EMPIRICAL RESEARCH}

A vizsgálat célja a szakirodalmi áttekintés során bemutatott TFEQ rövidített skála adaptálása a magyarországi felnőtt lakosság körében, illetve az alábbi összefüggések vizsgálata:

- Van-e különbség az evési stílusok között nemek alapján?

- Van-e különbség az evési stílusok között életkor alapján?

A bemutatott szakirodalmi összefoglalás alapján előzetes feltételezésünk, hogy eltérő faktorstruktúrát, és azzal faktorsúlyokat találunk férfiak és nők, valamint a különböző generációk alapján. Mivel az általunk korábban ismertetett kutatások (ERCSEY , 2015) nem tértek ki az életkori eltérések hangsúlyozására, ezért ezeket mi kívánjuk feltárni. Feltevésünk szerint a 21. században fontos a külső megjelenés, ezért a fiatalok azok, akik tudatosan tesznek a szépségükért és nagyobb hangsúlyt helyeznek az egészséges étkezésre, odafigyelnek mit esznek, és képesek kontrollálni magukat (keveseb- 
bet esznek, mint amennyit szeretnének, nem esznek este későn, fogyókúráznak, ha felszednek pár kilót).

A kvantitatív vizsgálat során a következő hipotéziseket kívánjuk tesztelni (1. ábra):

H1: Az TFEQ 16 magyarországi adaptálása lehetséges, vagyis a felnőtt lakosság körében elkülöníthető a három evési faktor, nevezetesen a kontrollálatlan, a kognitív és az érzelmi evés faktora.

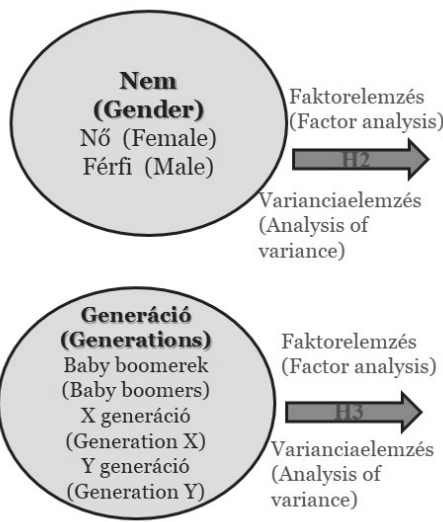

H2: Az evési stílusokat meghatározó változók közül eltérő súlyokat tapasztalhatunk a férfiak és a nők körében.

H3: A generációk közötti feltételezett különbségek eltérő faktorstruktúrát eredményeznek.

\section{1. ÁBRA}

A hipotézisek rendszere (The Conceptual Framework of Hypotheses)

FIG. 1 Forrás (Source): Saját szerkesztés (Own construction)

A kutatási kérdések megválaszolásához a primer kutatási módszerek közül az egyszeri keresztmetszeti kutatást választottuk. A terepmunka végrehajtására a kvótás mintavételi módszert alkalmaztuk. A mintavétel során arra törekedtünk, hogy nem és kor alapján proporcionális mintát kövessenek: 50-50\% a nők és férfiak aránya, illetve az öt korcsoport (19-25 év, 26-29 év, 30-39 év, 40-49 év, 50-59 év) egyenlő arányban képviseltesse magát (20\%20\%-ban). A tervezett mintanagyság 1000 fó volt. Az empirikus kutatás 2015 márciusában zajlott, önkitöltős kérdőív formájában online és papír alapon. A lekérdezésben a szerzők, és egyetemi hallgatók vettek részt, végezetül 919 főt sikerült elérni, 45,2\%-ban férfiakat, 54,8\%ban nőket. Életkor alapján a változó új kategóriáival meghatároztuk a három generációt, a Baby Boom nemzedéket, az X és az Y generációt. Ezek aránya rendre 14,7, 42,5 és 42,8\%.

Az adatelemzést az SPSS 22.0 szoftver segítségével végeztük el. A hipotéziseket több- változós statisztikai módszerekkel teszteltük. Az első hipotézis elemzéséhez faktorelemzést végeztünk. Faktorextrakciós módszernek a fökomponens elemzést választottuk. A főkomponensek számának meghatározása a varianciahányad módszer és a könyökszabály alapján történt. A faktorok rotálását Varimax módszerrel végeztük. A második hipotézist független mintás t próbával, a harmadik hipotézist pedig varianciaelemzéssel teszteltük, ahol a kapott faktorértékek alapján képzett új változókat tekintettük függő változónak, függetlennek pedig a csoportképző ismérveket (nem, generációk).

\section{A Kutatás EREDMÉNYEI - RESULTS OF THE EMPIRICAL RESEARCH}

A Háromfaktoros Evési kérdőív kapcsán 16 állítás került vizsgálat alá. Ebben az esetben a skála megbízhatóságát igazoló Cronbach féle 
alfa értéke 0,879, amely alapján a skálánk konzisztens. A faktorelemzés helyességét igazoló mutatók értéke megfelelő (KMO: 0,907; Bartlett: 5947,165; Sig. 0,00o). Korábbi nemzetközi publikációkkal egyezően három faktor különíthető el jelen kutatásban (1 és $1_{b}$ táblázat).

Az első faktor tartalmazza azokat a változókat, amelyek a negatív érzelmi állapotokat jellemzik és az ezek hatására történő evést. Ebben az esetben jelen kutatás eredménye tökéletesen megfelel a szakirodalomnak, ahol szintén meg- található az érzelmi evés faktora. A következő faktor magába foglalja mindazokat a változókat, amelyek a kontrollálatlan evés kategóriájába tartoznak, azaz mindaz, amely valamilyen külső inger hatására kelti fel az evés kényszerét. A következő, harmadik faktor a tudatos kontroll, azaz a visszafogott evés témakörét vizsgálják. Itt találhatóak azok a változók, amelyekben az elhízástól való félelem, a testsúlylyal kapcsolatos tudatos kontroll található meg (1 és $1_{b}$ táblázat).

1 TÁBLÁZAT

Faktorelemzés eredménye a Háromfaktoros Evési Kérdőív esetében

TABLE 1 (The Results of Factor Analysis in Case of Three Factor Eating Questionnaire)

\begin{tabular}{|c|c|c|}
\hline $\begin{array}{c}\text { Állítás } \\
\text { (Statement) }\end{array}$ & $\begin{array}{l}\text { Faktorsúly } \\
\text { (Factor } \\
\text { Loading) }\end{array}$ & $\begin{array}{l}\text { Faktor } \\
\text { (Factor) }\end{array}$ \\
\hline $\begin{array}{l}\text { Amikor szomorú vagyok, gyakran túl sokat eszem (I usually eat } \\
\text { too much if I am sad) }\end{array}$ & 0,801 & \multirow{6}{*}{$\begin{array}{c}\text { érzelmi evés } \\
\text { (emotional } \\
\text { eating) } \\
38,76 ; 0,927\end{array}$} \\
\hline Amikor szorongok, enni kezdek (When I am stressed, I eat) & 0,796 & \\
\hline $\begin{array}{l}\text { Amikor feszült vagyok, vagy fel vagyok húzva, gyakran úgy érzem, } \\
\text { hogy ennem kell (When I am stressed or upset, I often feel I must } \\
\text { eat) }\end{array}$ & 0,761 & \\
\hline $\begin{array}{l}\text { Amikor ideges vagyok, evéssel próbálom megnyugtatni magam } \\
\text { (When I feel anxious, I find myself eating) }\end{array}$ & 0,758 & \\
\hline $\begin{array}{l}\text { Amikor levert vagyok, enni akarok (When I feel blue, I often } \\
\text { overeat) }\end{array}$ & 0,724 & \\
\hline $\begin{array}{l}\text { Amikor magányos vagyok, evéssel vigasztalódom (When I feel } \\
\text { lonely, I console myself by eating) }\end{array}$ & 0,709 & \\
\hline $\begin{array}{l}\text { Amikor egy étvágygerjesztő ételt látok, vagy illatát érzem, nagyon } \\
\text { nehezen állom meg, hogy ne egyek, még akkor is, ha épp akkor } \\
\text { fejeztem be az evést (When I see a delicious food or I can smell } \\
\text { it, I find it very difficult to keep from eating, even if I have just } \\
\text { finished a meal) }\end{array}$ & 0,754 & \multirow{4}{*}{$\begin{array}{l}\text { kontrollálatlan } \\
\text { evés } \\
\text { (uncontrolled } \\
\text { eating) } \\
12,54 ; 0,829\end{array}$} \\
\hline $\begin{array}{l}\text { Amikor valami finomat látok, gyakran olyan éhes leszek, hogy } \\
\text { azonnal ennem kell (When I see a real delicacy, I often get so } \\
\text { hungry that I have to eat right away) }\end{array}$ & 0,725 & \\
\hline $\begin{array}{l}\text { Mindig elég éhes vagyok ahhoz, hogy bármikor tudjak enni (I am } \\
\text { always hungry enough to eat at any time) }\end{array}$ & 0,695 & \\
\hline $\begin{array}{l}\text { Ha olyan valakivel vagyok együtt, aki eszik, gyakran engem is } \\
\text { arra késztet, hogy egyek (Being with someone who is eating often } \\
\text { makes me hungry enough to eat also) }\end{array}$ & 0,645 & \\
\hline
\end{tabular}

Forrás (Source): Saját kutatás, $\mathrm{n}=919$ fó. Módszer: Főkomponens elemzés, Forgatás: Varimax (Own construction, $n=919$ respondents. Method: Principle component analysis, Rotation: Varimax) Megjegyzés (Note): A faktorok mögötti első szám a magyarázott variancia, a második a Cronbach féle alfa értéke (The numbers behind the factors refer to the explained variance and the Cronbach's alpha in this order.) 
1

Faktorelemzés eredménye a Háromfaktoros Evési Kérdőív esetében

TABLE $1_{b}$ (The Results of Factor Analysis in Case of Three Factor Eating Questionnaire)

\begin{tabular}{|c|c|c|}
\hline $\begin{array}{c}\text { Állítás } \\
\text { (Statement) }\end{array}$ & $\begin{array}{l}\text { Faktorsúly } \\
\text { (Factor } \\
\text { Loading) }\end{array}$ & $\begin{array}{l}\text { Faktor } \\
\text { (Factor) }\end{array}$ \\
\hline $\begin{array}{l}\text { Mindig annyira éhes vagyok, hogy nehezemre esik abbahagyni az } \\
\text { evést, amíg teljesen el nem fogyasztottam a tányéromon lévó ételt } \\
\text { (I am always hungry so it is hard for me to stop eating before I } \\
\text { finish the food on my plate) }\end{array}$ & 0,621 & \multirow{3}{*}{$\begin{array}{c}\begin{array}{c}\text { kontrollálatlan } \\
\text { evés }\end{array} \\
\text { (uncontrolled } \\
\text { eating) } \\
12,54 ; 0,829\end{array}$} \\
\hline $\begin{array}{l}\text { Amikor enni kezdek, néha úgy érzem, nem tudom abbahagyni } \\
\text { (Sometimes when I start eating, I just can't seem to stop) }\end{array}$ & 0,582 & \\
\hline $\begin{array}{l}\text { Gyakran annyira éhes vagyok, hogy feneketlen ûrt érzek a gyom- } \\
\text { rom helyén (I get so hungry that my stomach often seems like a } \\
\text { bottomless pit) }\end{array}$ & 0,569 & \\
\hline $\begin{array}{l}\text { Tudatosan korlátozom, hogy mennyit eszem az étkezések során, } \\
\text { hogy elkerüljem a hízást (I consciously hold back at meals in } \\
\text { order not to weight gain) }\end{array}$ & 0,85 & \multirow{3}{*}{ 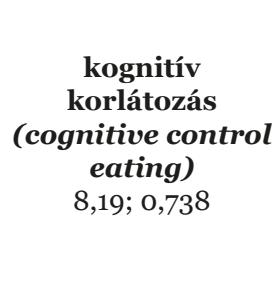 } \\
\hline $\begin{array}{l}\text { Bizonyos ételeket azért nem eszek, mert hizlalnak (I do not eat } \\
\text { some foods because they make me fat) }\end{array}$ & 0,804 & \\
\hline $\begin{array}{l}\text { Szándékosan keveset eszem egyszerre, hogy kordában tartsam a } \\
\text { testsúlyomat (I deliberately take small helpings as a means of } \\
\text { controlling my weight) }\end{array}$ & 0,762 & \\
\hline
\end{tabular}

Forrás (Source): Saját kutatás, $\mathrm{n}=919$ fő. Módszer: Fókomponens elemzés, Forgatás: Varimax (Own construction, $n=919$ respondents. Method: Principle component analysis, Rotation: Varimax)

Megjegyzés (Note): A faktorok mögötti első szám a magyarázott variancia, a második a Cronbach féle alfa értéke (The numbers behind the factors refer to the explained variance and the Cronbach's alpha in this order.)

A faktorelemzés eredménye alapján az első hipotézist abban az értelemben elfogadtuk, hogy a szakirodalomban fellelhető faktorstruktúrát igazoltuk, azaz ugyanabban a felépítésben található meg a három faktor, az érzelmi evés, a kontrollálatlan evés és a kognitív korlátozás.

\subsection{Nemekból fakadó eltérések - Differences Based on Gender}

Érdemes annak vizsgálata, hogy a nemből fakadó eltérések eredményeznek-e eltérő faktorstruktúrát, vagy faktorsúlyokat a vizsgált mintában.

A női alminta esetében a skála megbízhatóságát igazoló Cronbach féle alfa értéke 0,856 , amely alapján a skálánk konzisztens. A faktorelemzés helyességét igazoló mutatók értéke megfelelő (KMO: 0,889; Bartlett: 3060,497; Sig. 0,000). A teljes mintára lefuttatott elemzésnek megfelelően itt is a három faktor került igazolásra.
A férfi alminta esetében a skála megbízhatóságát igazoló Cronbach féle alfa értéke 0,901, amely alapján a skálánk itt is konzisztens. A faktorelemzés helyességét igazoló mutatók értéke megfelelő (KMO: 0,911; Bartlett: 3023,554; Sig. 0,000). A teljes mintára lefuttatott elemzésnek megfelelően itt is a három faktor került igazolásra, akárcsak a korábbi alminta esetében.

Minimális eltérés adódik a nők és a férfiak között. Látható, hogy mindegyik esetben ugyanaz a faktorstruktúra, az eltérés csak a faktorsúlyokban van, azonban ez a faktorokban nem hoz változást ( $2_{a}$ és $2_{b}$ táblázat).

A magyarázott variancia és az adott, almintákhoz köthető alfa értékek között sincs nagy eltérés (3. táblázat). 
Faktorok és faktorsúlyok nem alapján

TABLE 2 (Factors and Factor Loadings Based on Gender)

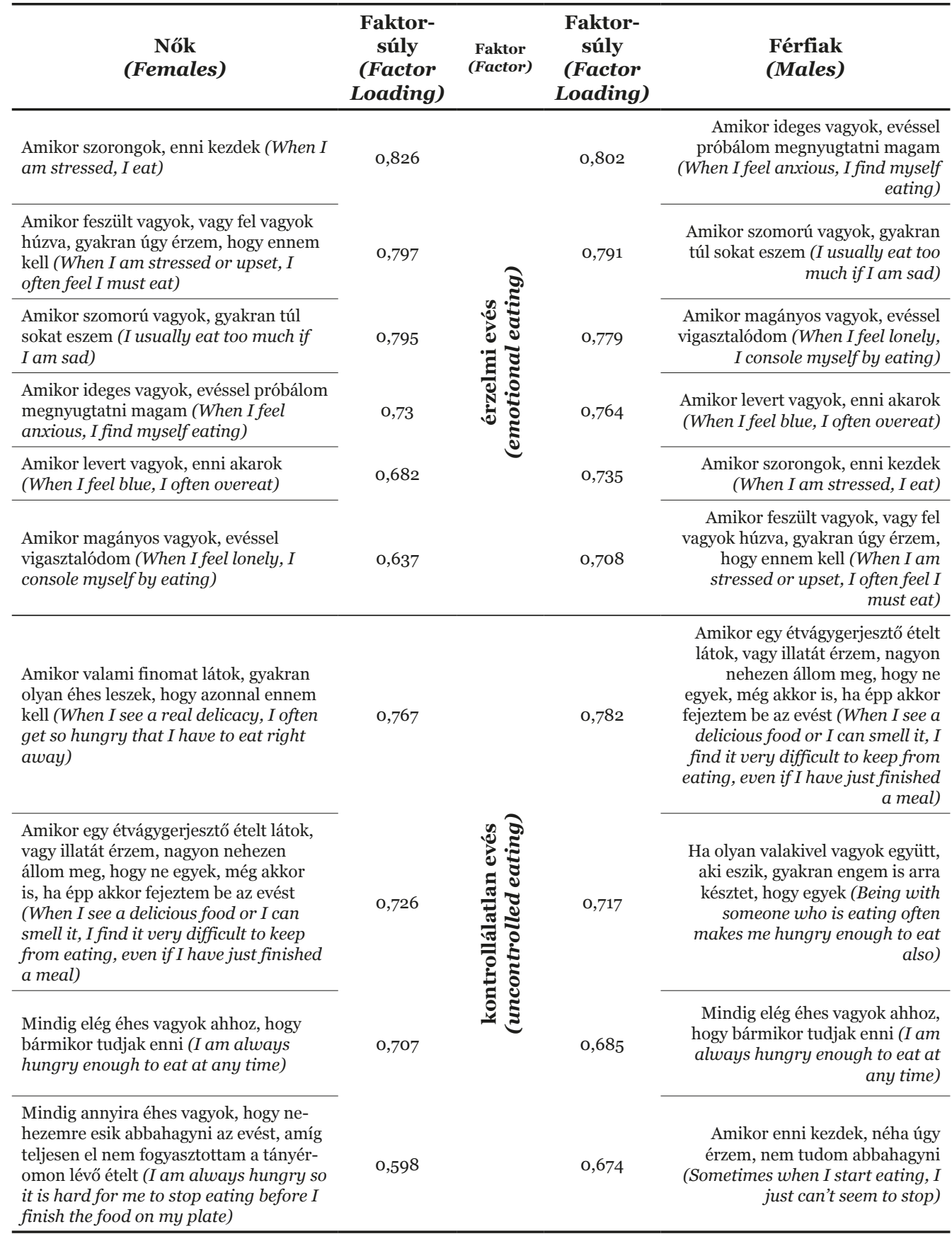

Forrás (Source): Saját kutatás, $\mathrm{n}=919$ fó. Módszer: Főkomponens elemzés, Forgatás: Varimax

(Own research, $n=919$ respondents. Method: Principle component analysis, Rotation: Varimax 
Keller, V. - Dernóczy-Polyák, A. - Ercsey, I.

2. TÁBLÁZAT

Faktorok és faktorsúlyok nem alapján

TABLE 2 (Factors and Factor Loadings Based on Gender)

\begin{tabular}{|c|c|c|c|c|}
\hline $\begin{array}{c}\text { Nók } \\
\text { (Females) }\end{array}$ & $\begin{array}{l}\text { Faktor- } \\
\text { súly } \\
\text { (Factor } \\
\text { Loading) }\end{array}$ & $\begin{array}{c}\text { Faktor } \\
\text { (Factor) }\end{array}$ & $\begin{array}{l}\text { Faktor- } \\
\text { súly } \\
\text { (Factor } \\
\text { Loading) }\end{array}$ & $\begin{array}{l}\text { Férfiak } \\
\text { (Males) }\end{array}$ \\
\hline $\begin{array}{l}\text { Ha olyan valakivel vagyok együtt, aki } \\
\text { eszik, gyakran engem is arra késztet, } \\
\text { hogy egyek (Being with someone who is } \\
\text { eating often makes me hungry enough } \\
\text { to eat also) }\end{array}$ & \multirow[t]{2}{*}{0,597} & \multirow{3}{*}{ 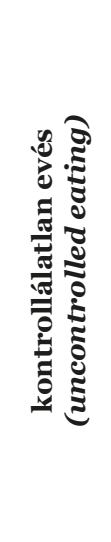 } & 0,67 & $\begin{array}{r}\text { Amikor valami finomat látok, } \\
\text { gyakran olyan éhes leszek, hogy } \\
\text { azonnal ennem kell (When I see a } \\
\text { real delicacy, I often get so hungry } \\
\text { that I have to eat right away) }\end{array}$ \\
\hline $\begin{array}{l}\text { Gyakran annyira éhes vagyok, hogy } \\
\text { feneketlen ürt érzek a gyomrom helyén } \\
\text { (I get so hungry that my stomach often } \\
\text { seems like a bottomless pit) }\end{array}$ & & & 0,633 & $\begin{array}{r}\text { Mindig annyira éhes vagyok, hogy } \\
\text { nehezemre esik abbahagyni az } \\
\text { evést, amíg teljesen el nem fogyasz- } \\
\text { tottam a tányéromon lévó ételt (I } \\
\text { am always hungry so it is hard for } \\
\text { me to stop eating before I finish } \\
\text { the food on my plate) }\end{array}$ \\
\hline $\begin{array}{l}\text { Amikor enni kezdek, néha úgy érzem, } \\
\text { nem tudom abbahagyni (Sometimes } \\
\text { when I start eating, I just can't seem } \\
\text { to stop.) }\end{array}$ & 0,469 & & 0,523 & $\begin{array}{r}\text { Gyakran annyira éhes vagyok, hogy } \\
\text { feneketlen űrt érzek a gyomrom } \\
\text { helyén (I get so hungry that my } \\
\text { stomach often seems like a bottom- } \\
\text { less pit) }\end{array}$ \\
\hline $\begin{array}{l}\text { Tudatosan korlátozom, hogy mennyit } \\
\text { eszem az étkezések során, hogy elkerül- } \\
\text { jem a hízást (I consciously hold back at } \\
\text { meals in order not to weight gain) }\end{array}$ & \multirow[b]{2}{*}{0,813} & \multirow{3}{*}{ 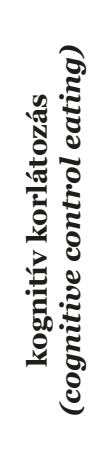 } & 0,828 & $\begin{array}{r}\text { Tudatosan korlátozom, hogy meny- } \\
\text { nyit eszem az étkezések során, hogy } \\
\text { elkerüljem a hízást (I consciously } \\
\text { hold back at meals in order not to } \\
\text { weight gain) }\end{array}$ \\
\hline $\begin{array}{l}\text { Bizonyos ételeket azért nem eszek, } \\
\text { mert hizlalnak (I do not eat some foods } \\
\text { because they make me fat) }\end{array}$ & & & 0,804 & $\begin{array}{r}\text { Szándékosan keveset eszem } \\
\text { egyszerre, hogy kordában tartsam } \\
\text { a testsúlyomat (I deliberately } \\
\text { take small helpings as a means of } \\
\text { controlling my weight) }\end{array}$ \\
\hline $\begin{array}{l}\text { Szándékosan keveset eszem egyszerre, } \\
\text { hogy kordában tartsam a testsúlyomat } \\
\text { (I deliberately take small helpings as a } \\
\text { means of controlling my weight) }\end{array}$ & 0,71 & & 0,779 & $\begin{array}{l}\text { Bizonyos ételeket azért nem eszek, } \\
\text { mert hizlalnak (I do not eat some } \\
\text { foods because they make me fat) }\end{array}$ \\
\hline
\end{tabular}

Forrás (Source): Saját kutatás, n = 919 fő. Módszer: Fókomponens elemzés, Forgatás: Varimax (Own research, $n=919$ respondents. Method: Principle component analysis, Rotation: Varimax

A magyarázott variancia és a Cronbach alfa (Explained Variance and Value of Cronbach's Alpha)

\begin{tabular}{lcccc}
\hline \multirow{2}{*}{$\begin{array}{c}\text { Faktorok } \\
\text { (Factors) }\end{array}$} & \multicolumn{2}{c}{$\begin{array}{c}\text { Magyarázott Variancia } \\
\text { (Explained Variance) }\end{array}$} & \multicolumn{2}{c}{$\begin{array}{c}\text { Cronbach Alfa } \\
\text { (Cronbach's Alpha) }\end{array}$} \\
\cline { 2 - 5 } & $\begin{array}{c}\text { Férfi } \\
\text { (Male) }\end{array}$ & $\begin{array}{c}\text { Nó } \\
\text { (Female) }\end{array}$ & $\begin{array}{c}\text { Férfi } \\
\text { (Male) }\end{array}$ & $\begin{array}{c}\text { Nő } \\
\text { (Female) }\end{array}$ \\
\hline érzelmi evés (emotional eating) & 42,243 & 36,451 & 0,908 & 0,888 \\
kontrollálatlan evés (uncontrolled eating) & 11,971 & 12,549 & 0,845 & 0,815 \\
kognitív korlátozás (cognitive control eating) & 7,995 & 8,706 & 0,76 & 0,705 \\
\hline
\end{tabular}

Forrás (Source): Saját kutatás (Own research) 
Ha a továbbiakban a faktorértékeket alapul véve vizsgáljuk tovább a mintán belüli eltéréseket, statisztikailag szignifikáns eredményeket kapunk. A faktorértékek és a nemek közötti kapcsolat vizsgálatára a független mintás t próba alkalmas.

TABLE 4

A független mintás t-próba eredménye (Result of Independent Samples T-tests)

\begin{tabular}{llcccc}
\hline & \multicolumn{5}{c}{ T teszt (t-test for Equality of Means) } \\
\cline { 2 - 6 } & & $\mathbf{t}$ & df & $\begin{array}{c}\text { Sig. } \\
\text { (2-tailed) }\end{array}$ & Mean Difference \\
\hline $\begin{array}{l}\text { érzelmi evés faktor- } \\
\text { érték } \\
\text { (emotional eating) }\end{array}$ & $\begin{array}{l}\text { evf/eva } \\
\text { evnf/ } \\
\text { evna }^{\mathrm{b}}\end{array}$ & 2,876 & 849 &, 004 & 0,19733505 \\
\hline $\begin{array}{l}\text { kontrollálatlan } \\
\text { evés faktor-érték } \\
\begin{array}{l}\text { (uncontrolled } \\
\text { eating) }\end{array}\end{array}$ & $\begin{array}{l}\text { evf/eva }^{\mathrm{a}} \\
\text { evnf/ }\end{array}$ &,- 738 & 849 &, 461 & 0,19733505 \\
\hline $\begin{array}{l}\text { evna } \\
\text { kognitív faktor-érték } \\
\text { (cognitive eating) }\end{array}$ & $\begin{array}{l}\text { evf/ev } \\
\text { evnf/ }\end{array}$ & 5,731 & 782,148 &, 465 & $-0,05088335$ \\
evna $^{\mathrm{b}}$ & 5,501 & 818,355 &, 005088335 \\
\hline
\end{tabular}

a egyenlő varianciákat feltételezve; ' nem egyenlő varianciákat feltételezve ( ${ }^{a}$ equal variances assumed; ${ }^{b}$ equal variances not assumed)

Forrás (Source): Saját kutatás (Own research)

Megjegyzés (Note): szignifikanicia 0,05 (level of significance o.05)

A t teszt alapján látható, hogy statisztikailag szignifikáns eltérés van a férfiak és a nők között az érzelmi evés és a kognitív evés tekintetében is (4. táblázat). Figyelembe véve az értékeket kijelenthetjük, hogy a nók inkább igaznak érzik (érzelmi faktorérték átlag: -0,09; szórás: 1,00; kognitív faktorérték átlag: -0,172; szórás: 0,987) magukra ezeket az állításokat, míg a férfiak inkább nem igaznak (érzelmi faktorérték átlag: -0,107; szórás: 0,985; kognitív faktorérték átlag: 0,198; szórás: 0,965). Ebben az esetben a negatív értékek az adott faktortól való baloldali elhelyezkedést sugallják a faktortérben, amely jelen esetben a skála egyetértő értékei, míg a pozitív értékek a jobboldali elhelyezkedést, azaz a skála negatív értékeit jelentik.

Ezek alapján a „H2: Az evési stílusokat meghatározó változók közül eltérő súlyokat tapasztalhatunk a férfiak és a nők körében" elméleti hipotézishez köthető azon nullhipotézist, mely szerint nincs eltérés az alminták között, elutasítjuk. Az elfogadott tézis és az eredmények alapján a nőkre inkább jellemző mind az érzelmi evés és mind a kognitív korlátozás, mint a férfiakra.

\subsection{Generációs eltérések - Differences Based on Generation}

A generációk és a faktorértékek közötti kapcsolat feltárására elsőként az almintákra lefuttatott faktorelemzésekben kerestük a választ. Ha figyelembe vesszük az eltéréseket a generációk alapján, érdekes eredményre jutunk. A Baby Boomerek és az X generáció bár eltérő faktorsúlyokkal, de hozzák a szakirodalomban fellelhető faktorstruktúrát, azonban az Y generáció ettől merőben eltérő. Elsőként bemutatjuk a Baby boom és az X generáció eredményeit ( $5_{a}$ és $5_{b}$ táblázat).

Hasonlóan a szakirodalomhoz, itt is a három evési faktor található meg, eltérés csak a faktorsúlyokban van. A magyarázott variancia és a Cronbach alfa értékeit a 6. táblázat mutatja. 
Baby Boom és $\mathrm{X}$ generáció

(Baby Boomers and $X$ Generation)

Nók
(Females)

\begin{tabular}{|c|c|c|}
\hline $\begin{array}{c}\text { Faktor- } \\
\text { súly } \\
\text { (Factor } \\
\text { Loading) }\end{array}$ & $\begin{array}{c}\text { Faktor } \\
\text { (Factor) }\end{array}$ & $\begin{array}{c}\text { Faktor- } \\
\text { súly } \\
\text { (Factor } \\
\text { Loading) }\end{array}$ \\
\hline
\end{tabular}

$0,893 \quad 0,818$

0,823

0,818

Amikor levert vagyok, enni akarok (When I feel blue, I often overeat)
0,804

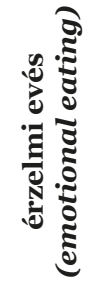

0,789

0,783

0,784

0,741

0,778

0,804

(1)

0,656

0,744
Férfiak

(Males)
Amikor szorongok, enni kezdek (When I am stressed, I eat)

Amikor szomorú vagyok, gyakran túl sokat eszem (I usually eat too much if I am sad)

Amikor ideges vagyok, evéssel próbálom megnyugtatni magam (When I feel anxious, I find myself eating)

Amikor feszült vagyok, vagy fel vagyok húzva, gyakran úgy érzem, hogy ennem kell (When I am stressed or upset, I often feel I must eat)

Amikor levert vagyok, enni akarok (When Ifeel blue, I often overeat)

Amikor magányos vagyok, evéssel vigasztalódom (When I feel lonely, I console myself by eating)

Amikor egy étvágygerjesztő ételt látok, vagy illatát érzem, nagyon nehezen állom meg, hogy ne

Amikor enni kezdek, néha úgy érzem, nem tudom abbahagyni (Sometimes when I start eating, I just can't seem
0,608
0,766

egyek, még akkor is, ha épp akkor fejeztem be az evést (When I see a delicious food or I can smell it, I find it very difficult to keep from eating, even if I have just finished a meal)

Amikor valami finomat látok, gyakran olyan éhes leszek, hogy

Mindig elég éhes vagyok ahhoz, hogy bármikor tudjak enni (I am always hungry enough to eat at any time)

azonnal ennem kell (When I see a real delicacy, I often get so hungry that I have to eat right away)

Mindig annyira éhes vagyok, hogy nehezemre esik abbahagyni az evést, amíg teljesen el nem fogyasztottam a tányéromon lévő ételt (I am always hungry so it is hard for me to stop eating before I finish the food on my plate)

Amikor valami finomat látok, gyakran olyan éhes leszek, hogy azonnal ennem kell (When I see a real delicacy, I often get so hungry that I have to eat right away)

Mindig elég éhes vagyok ahhoz, hogy bármikor tudjak enni (I am always hungry enough to eat at any time)

Forrás (Source): Saját kutatás, $\mathrm{n}=919$ fó. Módszer: Fókomponens elemzés, Forgatás: Varimax (Own research, $n=919$ respondents. Method: Princple component analysis, Rotation: Varimax) 
Baby Boom és $\mathrm{X}$ generáció

TABLE $5_{b}$ (Baby Boomers and $X$ Generation)

\begin{tabular}{|c|c|c|c|c|}
\hline $\begin{array}{c}\text { Nők } \\
\text { (Females) }\end{array}$ & $\begin{array}{l}\text { Faktor- } \\
\text { súly } \\
\text { (Factor } \\
\text { Loading) }\end{array}$ & $\begin{array}{c}\text { Faktor } \\
\text { (Factor) }\end{array}$ & $\begin{array}{l}\text { Faktor- } \\
\text { súly } \\
\text { (Factor } \\
\text { Loading) }\end{array}$ & $\begin{array}{l}\text { Férfiak } \\
\text { (Males) }\end{array}$ \\
\hline $\begin{array}{l}\text { Gyakran annyira éhes vagyok, hogy } \\
\text { feneketlen ürt érzek a gyomrom helyén } \\
\text { (I get so hungry that my stomach often } \\
\text { seems like a bottomless pit) }\end{array}$ & \multirow[b]{2}{*}{0,566} & \multirow{3}{*}{ 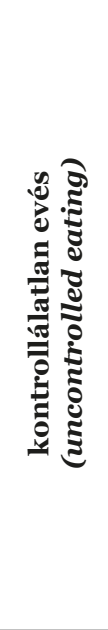 } & 0,657 & $\begin{array}{r}\text { Mindig annyira éhes vagyok, hogy } \\
\text { nehezemre esik abbahagyni az } \\
\text { evést, amíg teljesen el nem fogyasz- } \\
\text { tottam a tányéromon lévő ételt (I } \\
\text { am always hungry so it is hard for } \\
\text { me to stop eating before I finish } \\
\text { the food on my plate) }\end{array}$ \\
\hline $\begin{array}{l}\text { Amikor egy étvágygerjesztő ételt látok, } \\
\text { vagy illatát érzem, nagyon nehezen } \\
\text { állom meg, hogy ne egyek, még akkor } \\
\text { is, ha épp akkor fejeztem be az evést } \\
\text { (When I see a delicious food or I can } \\
\text { smell it, I find it very difficult to keep } \\
\text { from eating, even if I have just finished } \\
\text { a meal) }\end{array}$ & & & 0,615 & $\begin{array}{r}\text { Amikor enni kezdek, néha úgy } \\
\text { érzem, nem tudom abbahagyni } \\
\text { (Sometimes when I start eating, I } \\
\text { just can't seem to stop) }\end{array}$ \\
\hline $\begin{array}{l}\text { Ha olyan valakivel vagyok együtt, aki } \\
\text { eszik, gyakran engem is arra késztet, } \\
\text { hogy egyek (Being with someone who is } \\
\text { eating often makes me hungry enough } \\
\text { to eat also) }\end{array}$ & 0,227 & & 0,474 & $\begin{array}{r}\text { Gyakran annyira éhes vagyok, hogy } \\
\text { feneketlen ürt érzek a gyomrom } \\
\text { helyén (I get so hungry that my } \\
\text { stomach often seems like a bottom- } \\
\text { less pit) }\end{array}$ \\
\hline $\begin{array}{l}\text { Tudatosan korlátozom, hogy mennyit } \\
\text { eszem az étkezések során, hogy elkerül- } \\
\text { jem a hízást (I consciously hold back at } \\
\text { meals in order not to weight gain) }\end{array}$ & \multirow[t]{2}{*}{0,837} & \multirow{3}{*}{ 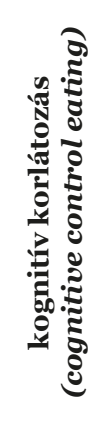 } & 0,851 & $\begin{array}{r}\text { Tudatosan korlátozom, hogy meny- } \\
\text { nyit eszem az étkezések során, hogy } \\
\text { elkerüljem a hízást (I consciously } \\
\text { hold back at meals in order not to } \\
\text { weight gain) }\end{array}$ \\
\hline $\begin{array}{l}\text { Bizonyos ételeket azért nem eszek, } \\
\text { mert hizlalnak (I do not eat some foods } \\
\text { because they make me fat) }\end{array}$ & & & 0,824 & $\begin{array}{l}\text { Bizonyos ételeket azért nem eszek, } \\
\text { mert hizlalnak (I do not eat some } \\
\text { foods because they make me fat) }\end{array}$ \\
\hline $\begin{array}{l}\text { Szándékosan keveset eszem egyszerre, } \\
\text { hogy kordában tartsam a testsúlyomat } \\
\text { (I deliberately take small helpings as a } \\
\text { means of controlling my weight) }\end{array}$ & 0,743 & & 0,758 & $\begin{array}{r}\text { Szándékosan keveset eszem } \\
\text { egyszerre, hogy kordában tartsam } \\
\text { a testsúlyomat (I deliberately } \\
\text { take small helpings as a means of } \\
\text { controlling my weight) }\end{array}$ \\
\hline
\end{tabular}

Forrás (Source): Saját kutatás, $\mathrm{n}=919$ fő. Módszer: Főkomponens elemzés, Forgatás: Varimax

(Own research, $n=919$ respondents. Method: Princple component analysis, Rotation: Varimax)

6. TÁBLÁZZAT

TABLE 6 A generációk faktorelemzésének fóbb mutatói
(Results of Factor Analysis Based on Generation)

\begin{tabular}{|c|c|c|c|c|}
\hline \multirow[b]{2}{*}{$\begin{array}{l}\text { Faktorok } \\
\text { (Factors) }\end{array}$} & \multicolumn{2}{|c|}{$\begin{array}{l}\text { Magyarázott Variancia } \\
\text { (Explained Variance) }\end{array}$} & \multicolumn{2}{|c|}{$\begin{array}{l}\text { Cronbach Alfa } \\
\text { (Cronbach's Alpha) }\end{array}$} \\
\hline & $\begin{array}{c}\text { Baby } \\
\text { Boom } \\
\text { (Baby } \\
\text { Boomers) }\end{array}$ & $\begin{array}{c}\mathrm{X} \\
\text { generáció } \\
\text { (Generation } \\
\boldsymbol{X}) \\
\end{array}$ & $\begin{array}{c}\text { Baby } \\
\text { Boom } \\
\text { (Baby } \\
\text { Boomers) } \\
\end{array}$ & $\begin{array}{c}\mathrm{X} \\
\text { generáció } \\
\text { (Generation } \\
X) \\
\end{array}$ \\
\hline érzelmi evés (emotional eating) & 39,901 & 38,949 & 0,910 & 0,912 \\
\hline kontrollálatlan evés (uncontrolled eating) & 11,857 & 14,527 & 0,800 & 0,841 \\
\hline kognitív korlátozás (cognitive control eating) & 8,225 & 8,628 & 0,714 & 0,741 \\
\hline
\end{tabular}

Forrás (Source): Saját kutatás (Own research) 
Az Y generáció azonban jelentősen módosítja a korábbi faktorstruktúrát. Az előző esetektől eltérően a legnagyobb varianciát ebben az esetben a kontrollálatlan faktor alkotja (eltérés egy változó; a „Mindig annyira éhes vagyok, hogy nehezemre esik abbahagyni az evést, amíg teljesen el nem fogyasztottam a tányéromon lévő ételt" változó a következő faktorba kerül faktorsúly alapján), ami 38,682\%. A többi generációnál ez jóval kisebb értéket képvisel. A második legnagyobb faktor ese- tében már jelentősebb eltérést találhatunk. A korábbi érzelmi faktor most kettéválik (ezt igazolják a magas faktorsúlyok; megbízhatóságát a Cronbach alfa értékek). A második faktor ennek megfelelően az érzelmi vigasz nevet kapta (magyarázza a variancia 11,746\%-át), a harmadik szintén e módszer alapján az érzelmi szorongás (variancia 7,920\%), és a negyedik a szakirodalomból is ismert kognitív faktor ( $7_{a}$ és $7_{b}$ táblázat).

$\begin{array}{ccc}\text { Állítás } & \text { Faktorsúly } \\ \text { (Statement) } & \begin{array}{c}\text { (Factor } \\ \text { Loading) }\end{array} & \begin{array}{c}\text { Faktor } \\ \text { (Factor) }\end{array}\end{array}$

Amikor egy étvágygerjesztő ételt látok, vagy illatát érzem, nagyon nehezen állom meg, hogy ne egyek, még akkor is, ha épp akkor fejeztem be az evést (When I see a delicious food or I can smell it, I find it very difficult to keep from eating, even if I have just finished a meal)

Ha olyan valakivel vagyok együtt, aki eszik, gyakran engem is arra késztet, hogy egyek (Being with someone who is eating often makes me hungry enough to eat also)

Gyakran annyira éhes vagyok, hogy feneketlen ürt érzek a gyomrom helyén (I get so hungry that my stomach often seems like a bottomless pit)

Amikor valami finomat látok, gyakran olyan éhes leszek, hogy azonnal ennem kell (When I see a real delicacy, I often get so hungry that I have to eat right away)

Amikor enni kezdek, néha úgy érzem, nem tudom abbahagyni (Sometimes when I start eating, I just can't seem to stop)

0,592

Mindig elég éhes vagyok ahhoz, hogy bármikor tudjak enni ( $I$ am always hungry enough to eat at any time)

0,703

0,618

kontrollálatlan (uncontrolled) 38,$682 ; 0,802$

\begin{tabular}{|c|c|c|}
\hline $\begin{array}{l}\text { Amikor levert vagyok, enni akarok (When I feel blue, I often } \\
\text { overeat) }\end{array}$ & 0,743 & \multirow{4}{*}{$\begin{array}{c}\text { érzelmi vigasz } \\
\text { (emotional, } \\
\text { comfort) } \\
11,746 ; 0,801\end{array}$} \\
\hline $\begin{array}{l}\text { Amikor ideges vagyok, evéssel próbálom megnyugtatni magam } \\
\text { (When I feel anxious, I find myself eating) }\end{array}$ & 0,728 & \\
\hline $\begin{array}{l}\text { Amikor magányos vagyok, evéssel vigasztalódom (When I feel } \\
\text { lonely, I console myself by eating) }\end{array}$ & 0,704 & \\
\hline $\begin{array}{l}\text { Mindig annyira éhes vagyok, hogy nehezemre esik abbahagyni az } \\
\text { evést, amíg teljesen el nem fogyasztottam a tányéromon lévő ételt } \\
\text { (I am always hungry so it is hard for me to stop eating before I } \\
\text { finish the food on my plate) }\end{array}$ & 0,507 & \\
\hline
\end{tabular}

Forrás (Source): Saját kutatás, $\mathrm{n}=919$ fő. Módszer: Fókomponens elemzés, Forgatás: Varimax (Own research, $n=919$ repondents. Method: Principle component analysis, Rotation: Varimax)

Megjegyzés (Note): A faktorok mögötti első szám a magyarázott variancia, a második a Cronbach féle alfa értéke (The numbers behind the factors refer to the explained variance and the Cronbach's alpha in this order.) 
(Results of Factor Analysis in Case of Y Generation)

\begin{tabular}{|c|c|c|}
\hline $\begin{array}{c}\text { Állítás } \\
\text { (Statement) }\end{array}$ & $\begin{array}{l}\text { Faktorsúly } \\
\text { (Factor } \\
\text { Loading) }\end{array}$ & $\begin{array}{l}\text { Faktor } \\
\text { (Factor) }\end{array}$ \\
\hline Amikor szorongok, enni kezdek (When I am stressed, I eat) & 0,827 & \multirow{3}{*}{$\begin{array}{c}\text { érzelmi szorongás } \\
\text { (emotional } \\
\text { anxiety) } \\
7,920 ; 0,847\end{array}$} \\
\hline $\begin{array}{l}\text { Amikor szomorú vagyok, gyakran túl sokat eszem (I usually eat } \\
\text { too much if I am sad) }\end{array}$ & 0,694 & \\
\hline $\begin{array}{l}\text { Amikor feszült vagyok, vagy fel vagyok húzva, gyakran úgy érzem, } \\
\text { hogy ennem kell (When I am stressed or upset, I often feel I must } \\
\text { eat) }\end{array}$ & 0,622 & \\
\hline $\begin{array}{l}\text { Tudatosan korlátozom, hogy mennyit eszem az étkezések során, } \\
\text { hogy elkerüljem a hízást (I consciously hold back at meals in } \\
\text { order not to weight gain) }\end{array}$ & 0,874 & \multirow{3}{*}{$\begin{array}{c}\text { kognitív kontroll } \\
\text { (cognitive } \\
\text { control) } \\
6,392 ; 0,740\end{array}$} \\
\hline $\begin{array}{l}\text { Bizonyos ételeket azért nem eszek, mert hizlalnak (I do not eat } \\
\text { some foods because they make me fat) }\end{array}$ & 0,791 & \\
\hline $\begin{array}{l}\text { Szándékosan keveset eszem egyszerre, hogy kordában tartsam a } \\
\text { testsúlyomat (I deliberately take small helpings as a means of } \\
\text { controlling my weight) }\end{array}$ & 0,729 & \\
\hline
\end{tabular}

Forrás (Source): Saját kutatás, $\mathrm{n}=919$ fö. Módszer: Főkomponens elemzés, Forgatás: Varimax (Own research, $n=919$ repondents. Method: Principle component analysis, Rotation: Varimax)

Megjegyzés (Note): A faktorok mögötti első szám a magyarázott variancia, a második a Cronbach féle alfa értéke (The numbers behind the factors refer to the explained variance and the Cronbach's alpha in this order.)

Ezek alapján tehát már sejthető az eltérés a generációk alapján. Igazolására szintén varianciaelemzést használunk. A Levene teszt alapján a szóráshomogenitás nem teljesül a kognitív faktor esetén, míg a másik két faktor megfelel ennek a kitételnek.

A kapott eredmények alapján statisztikailag szignifikáns eredménnyel két esetben találkozunk (8. táblázat). A kontrollálatlan és a kognitív faktor esetében jelentős az eltérés a generációk között. A H3: „Máshogy viszonyulnak a különböző faktorokhoz a különböző generációk" elméleti hipotézishez köthető azon nullhipotézist, mely szerint nincs eltérés az alminták között, elutasítjuk. A kognitív evés esetében szignifikáns eltérés a Baby Boom és az X generáció között van (Dunnett T3 Post Hoc alapján Mean Difference Baby Boom - X 0,28636, Sig. 0,002). A tudatos evés leginkább az X generációra (Átlag= -0,12; Szórás=0,988) jellemző, míg az Y (Átlag=0,022; Szórás=1,02) és a Baby Boom (Átlag=0,191; Szórás=0,897) nem érzi magára jellemzőnek ezt a fajta stílust. A kontrollálatlan evés esetében a Baby Boom és az Y generáció között találunk szignifikáns eltérést
(Dunnett T3 Post Hoc alapján Mean Difference Baby Boom - Y 0,22514; Sig. 0,002) Ezek mellett a kontrollálatlan evés leginkább az Y generációra (Átlag= -0,122; Szórás=1,01) jellemző, míg az X (Átlag=0,055; Szórás=1,004) és a Baby Boom (Átlag=0,202; Szórás=0,897) nem érzi magára jellemzőnek ezt. Az eta2 értéke szintén nagyon alacsony, a kontrollálatlan esetében 0,014, míg a kognitív faktor esetében 0,012 .

Empirikus kutatásunk alapján az alábbi megállapításokat tehetjük:

- A TFEQ 16 alkalmas az evési stílusok mérésére Magyarországon.

- A nőkre jellemző az érzelmi evés és a kognitív korlátozás evési stílus.

- Az Y generációra jellemző a kontrollálatlan evés, míg az X generációra a kognitív evés.

Összességében kijelenthető, hogy lehetséges a magyar lakosság evési stílus alapján történő szegmentációja és demográfiai ismérvek alapján történő tipizálása, ami jelen kutatás következő lépése. 
Varianciaelemzés a generációk kapcsán (Analysis of Variance Based on Generation)

\begin{tabular}{|c|c|c|c|c|c|}
\hline & $\begin{array}{c}\text { Eltérés- } \\
\text { négyzet } \\
\text { Összeg (SS) }\end{array}$ & df & $\mathbf{M S}=\mathbf{S S} / \mathbf{d f}$ & $\mathbf{F}$ & $\mathbf{p}$ \\
\hline \multirow{3}{*}{$\begin{array}{l}\text { Érzelmi evés faktorér- } \\
\text { ték* Generációk } \\
\text { (Emotional eating * } \\
\text { Generation) }\end{array}$} & 2,268 & 2 & 1,134 & \multirow[t]{3}{*}{1,719} & \multirow[t]{3}{*}{0,180} \\
\hline & 559,381 & 848 & 0,660 & & \\
\hline & 561,649 & 850 & & & \\
\hline \multirow{3}{*}{$\begin{array}{l}\text { Kontrollálatlan evés } \\
\text { faktorérték * Gene- } \\
\text { rációk } \\
\text { (Uncontrolled eating } \\
\text { * Generation) }\end{array}$} & 5,262 & 2 & 2,631 & \multirow[t]{3}{*}{5,537} & \multirow[t]{3}{*}{0,004} \\
\hline & 402,982 & 848 & $\mathrm{o}, 475$ & & \\
\hline & 408,244 & 850 & & & \\
\hline \multirow{3}{*}{$\begin{array}{l}\text { Kognitív evés fakto- } \\
\text { rérték* Generációk } \\
\text { (Cognitive eating * } \\
\text { Generation) }\end{array}$} & 7,998 & 2 & 3,999 & \multirow[t]{3}{*}{5,397} & \multirow[t]{3}{*}{0,005} \\
\hline & 628,323 & 848 & 0,741 & & \\
\hline & 636,320 & 850 & & & \\
\hline
\end{tabular}

Forrás (Source): Saját kutatás (Own research)

Megjegyzés (Note): szignifikanicia 0,05 (level of significance 0.05)

\section{A kutatás továbbfejleszté- SE, GYAKORLATI JELENTÓSÉGE \\ - Future Development AND the Practical Use of the Study}

Az üzleti élet számos területén tapasztalhatjuk, hogy óriási azoknak a vállalatoknak a térnyerése, amelyek az egészséges életmód felkarolása mellett döntenek. Folyamatosan terjed az egészséges alapanyagok előállításával készített ételek értékesítése az élelmiszerüzletekben, a paleo irányzat nagy népszerüségnek örvend, meglévő vállalkozások, éttermek, cukrászdák bővítik a kínálatukat az egészségesebb, kevésbé hizlaló alapanyagból készített termékekkel. „Egészségesen finomat” jelmondat lehet a hedonista fogyasztók számára, akik nem akarnak lemondani a csábító falatokról, ugyanakkor nem szeretnék, ha túlsúlyosak, elhízottak lennének.

Marketing szempontból fontosnak tartjuk a különböző csoportok megfelelő feltérképezését, valamint az eltérések azonosítását. Annak figyelembevételével, hogy milyen eltéréseket találhatunk a férfiak és nők, valamint a különböző generációk között, nagyon jól profilozhatóak lesznek ezek a csoportok. Az evési magatartás faktorai alapján klaszterek tipologizálásával azonosíthatóak lennének ezeken fe- lül olyan fogyasztói csoportok, amelyek leírhatók az élelmiszerfogyasztásukat jellemző evési magatartás alapján. A kutatás eredményei hozzájárulhatnak annak meghatározásához és kidolgozásához, hogy a marketing eszközök milyen módon javíthatják a fogyasztók egészségmagatartását és életminőségét.

\section{6. ÖSSZEFOGLALÁS - SUMMARY}

Az elhízás a fejlett országokat érintő népbetegség. A túlsúly és az elhízás, mint rizikófaktor komoly anyagi terhet jelent egyéni, foglalkoztatói és állami szinten, mind a megelőzés, mind a kezelés fázisában. A nemzetközi és hazai szakirodalomban több kutatás foglalkozik az egészségmagatartás dimenzióinak vizsgálatával komplex megközelítésben, vagy egyes kiemelt területekre (pl. dohányzás, alkoholfogyasztás, testmozgás, élelmiszerfogyasztás) fókuszálva. Az élelmiszerfogyasztás vizsgálatához kifejlesztett tesztek közül a Háromfaktoros Evési Kérdőív (TFEQ 21 és 18) magyarországi adaptálása már megtörtént. A hazai és külföldi kutatók az eredeti 51 tételes skála és annak rövidített változata értelmében három evési stílust azonosítottak elhízott és normál testsúlyú célcsoportokra: (1) érzelmi evés, (2) kognitív korlátozás 
és (3) a kontrollálatlan evés.

A tanulmány célja egyrészt az evési magatartással kapcsolatos rövidített skála (TFEQ 16) hazai adaptálási lehetőségének bemutatása, másrészt a demográfiai ismérvekkel való kapcsolat feltárása. Az empirikus kutatás keretében 919 felnőtt egyént sikerült elérni, 45,2\%-ban férfiakat, 54,8\%-ban nőket. Életkor alapján a Baby Boom nemzedék tagjai 14,7\%, az X és az Y generáció 42,5, 42,8\% arányban képviselteti magát a mintában. Jelen kutatás eredménye alátámasztotta a szakirodalomban fellelhető faktorstruktúrát, azaz ugyanabban a felépítésben található meg, az érzelmi evés a kontrollálatlan evés és a kognitív korlátozás. A nőkre inkább jellemző mind az érzelmi evés és mind a kognitív korlátozás, mint a férfiakra. A tudatos korlátozás nélküli evés leginkább az Y generáció jellegzetessége.

A kutatás jövőbeli iránya a fogyasztók evési magatartása alapján történő szegmentálása, illetve a rájuk irányuló marketingprogramok kidolgozása.

\section{IRODALOMJEGYZÉK - REFERENCES}

Czeglédi E. - Bartha E. - Urbán R.: $\mathrm{Az}$ evési magatartás összefüggéseinek vizsgálata főiskolai hallgatónóknél. In: Magyar Pszichológiai Szemle. 2011. 66 (3) 299-320.

Czeglédi E. - Urbán R.: A háromfaktoros evési kérdőív (Three Factor Eating Questionnaire Revised 21-item) hazai adaptációja. In: Magyar Pszichológiai Szemle. 2010. 65 (3) 463-494.

Ercsey I. - Dernóczy-P. A. - Keller V.: Étkezési stílusok Magyarországon - Az evési magatartás mérési módszerei. 2015. In: Marketing hálózaton innen és túl: $\mathrm{Az}$ Egyesület a Marketing Oktatásért és Kutatásért XXI. Országos Konferenciájának tanulmánykötete. 177187.

Garner, D. M. - Garfinkel, P. E.: The Eating Attitudes Test: An Index of the Symptoms of Anorexia Nervosa. In: Psychological Medicine. 1979. 9 273-279.
Harden, C. J. - Corfe, B. M. - Richardson, J. C. - Dettmar, P. W.: Body Mass Index and Age Affect Three-Factor Eating Questionnaire Scores in Male Subjects. In: Nutrition Research. 2009. 29 379-382.

Herman, C. P. - Polivy, J.: Restrained eating. In: Stunkard, A. J., editor. Obesity. 1980, Philadelphia Saunders; 208-225.

Huszka P. - Ercsey, I.: Fiatalok egészsége az életminőség és a fogyasztói magatartás tükrében. In: Táplálkozásmarketing. 2014. 1 (1-2) 87-95.

Kearney, D. J. - Milton, M. L. - Malte, C. A. - McDermott, K. A. - Martinez, M. - Simpson, T. L.: Participation in Mindfulness-based Stress Reduction is not Associated with Reductions in Emotional Eating or Uncontorlled Eating. In: Nutrition Research. 2012. 32 413-420.

Keränen, A-M. - Strengell, K. Savolainen, M. J. - Laitinen, J. H.: Effect of Weight Loss Intervention on the Association Between Eating Behaviour Measured by TFEQ-18 and Dietary Intake in Adults In: Appetite. 2011. 56 156-162.

KSH: Az egészségügyi kiadások legfőbb jellemzői, 2007-2012, In: Statisztikai Tükör. 2013. 98.

KSH: Európai Lakossági Egészségfelmérés, 2014, In: Statisztikai Tükör 2015. 29.

Lesdéma, A. - Fromentin, G. - Daudin, J. J. - Arlotti, A. - Vinoy, S. Tome, D. - Marsset-Baglieri, A.: Characterization of the Three-Factor Eating Questionnaire Score of a Young French Cohort, In: Apppetite. 2012. 59. 385-390.

Löffler, A. - Luck, T. - Then, F. S. Luppa, M. - Sikorski, C. - Kovacs, P. - Tönjes, A. - Böttcher, Y. Breitfeld, J. - Horstmann, A. Löffler, M. - Engel, C. - Thiery, J. - Stumvoll, M. - Riedel-Heller, S. G.: Age- and Gender-Specific Norms for the German Version of the Three-Factor Eatin-Questionnaire (TFEQ). In: Appetite. 2015. 91 241-247. 
Nurkkala, M. - Kaikkonen, K. Vanhala, M. L. - Karhunen, L. Keränen, A-M. - Korpelainen, R.: Lifestlyle Intervention has a Beneficial Effect on Eating Behavior and Long-term Weight Loss in Obese Adults. In: Eating Behaviors. 2015. 18. 179-185.

Pudel, V. - Metzdorff, M. - Oetting, M.: Zur Personlichkeit Adiposer in psychologischen Tests unter Berficksichtigung latent Fettsfichtiger. In: Zeitschrift für Psychosomatische Medizin. 1975. 21 345-361.

Stunkard, A. J. - Messick, S.: The Threefactor Eating Questionnaire to Measure Dietary Restraint, Disinhibition and Hunger. In: Journal of Psichosomatic Research. 1985. 40 71-83.
Szabó S. - Szigeti O. - Soós M. - Szakály Z.: Az élelmiszerfogyasztás mögöttes dimenziói: étkezési és testi attitüdök kapcsolata. In: Marketing Oktatók Klubja 20. Konferenciája, „Marketing megújulás”, Szeged, 2014. 1-10.

Tolnay P. - Szabó S. A.: Testtömegoptimálás, a sikeres fogyókúra ismérvei. In: Élelmezési Ipar. 2004. 58 (2) 60-61.

\section{JEGYZETEK $*$ NOTES}

